\title{
PENYULUHAN KESEHATAN MENGENAI BAHAYA ROKOK ELEKTRIK DENGAN METODE CERAMAH DI DESA UWUNG GIRANG, KECAMATAN CIBODAS, TANGERANG
}

\author{
Nurry Ayuningtyas Kusumastuti'1), Siti Haeriyah'1) \\ 1)Program Studi Kebidanan, STIKes Yatsi Tangerang, Tangerang, Banten, Indonesia \\ Corresponding author : Nurry Ayuningtyas Kusumastuti \\ Email: nurry0067@gmail.com
}

Diterima 03 Mei 2021, Direvisi 22 Mei 2021, Disetujui 25 Mei 2021

\begin{abstract}
ABSTRAK
Jumlah perokok di Indonesia adalah nomer satu di dunia. Kenaikan tarif Cukai Hasil Tembakau (CHT) atau cukai rokok menjadi alasan bagi para perokok untuk beralih ke rokok elektrik. Rokok elektrik merupakan penghantar nikotin elektronik. Kandungan di dalamnya adalah nikotin, zat karsinogenik, dan bahan toksik yang dapat menyebabkan inflamasi dan iritatif, serta mempengaruhi otak pada remaja. Tujuan pengabdian masyarakat ini adalah untuk meningkatkan pengetahuan dan pemahaman remaja mengenai bahaya rokok elektrik. Metode dalam pengabdian masyarakat ini menggunakan metode ceramah dengan media audio visual. Hasil dalam pengabdian masyarakat sebelum dilakukan penyuluhan kesehatan kepada remaja mengenai bahaya rokok elektrik mempunyai tingkat pengetahuan baik sebanyak 12 responden (40\%) dan 18 responden $(60 \%)$ tingkat pengetahuannya kurang baik. Setelah dilakukan penyuluhan kesehatan seluruh responden menjadi mempunyai pengetahuan yang baik. Hal tersebut menunjukkan bahwa perlunya dilakukan pengabdian masyarakat agar masyarakat mengerti bahaya rokok elektrik.
\end{abstract}

Kata Kunci : rokok elektrik; penyuluhan kesehatan; remaja

\begin{abstract}
Background: The number of smokers in Indonesia is number one in the world. The increasing product of tobacco excise rates (CHT) or cigarette excise is a reason for smokers to switch to e-cigarettes. Ecigarettes are electronic nicotine conductors. The content in it is nicotine, a carcinogenic substance, and toxic substances that can cause inflammation and irritation, and affect adolescent brain. The aim of this community dedication is to increase the knowledge and understanding of adolescent about the dangers of e-cigarettes. Method of community dedication used the lecture method with audio-visual media. Result of community dedication before got health education to adolescents regarding the dangers of ecigarettes had a good level 12 respondents $(40 \%)$ and 18 respondents $(60 \%)$ had a poor level of knowledge. After health education was carried out, all respondents $(100 \%)$ had good knowledge. This shows that needed for community dedication, so they would understand the dangers of e-cigarettes.
\end{abstract}

Keywords: e-cigarette; health education; adolescent.

\section{PENDAHULUAN}

Merokok merupakan salah satu ancaman terbesar kesehatan yang sudah menjadi kebiasaan yang sulit untuk dihilangkan. Bahkan tidak sedikit perokok yang berdalih bahwa merokok bukan merupakan kebiasaan buruk yang akan berdampak negatif terhadap kesehatan. Menurut data dari WHO pada tahun 2017, melaporkan sekitar $64,9 \%$ laki-laki dewasa di Indonesia adalah perokok, sedangkan pada perempuan sebesar $2,1 \%$. Jumlah perokok di Indonesia merupakan perokok nomer satu di dunia dengan persentase sekitar $57 \%$ di antaranya adalah laki-laki. Urutan kedua setelah Indonesia adalah Papua Nugini, Rusia dan China (Kementrian Kesehatan RI, 2018; Atlas, 2015).

Perokok tembakau banyak yang beralih menggunakan rokok elektrik karena adanya kenaikan tarif Cukai Hasil Tembakau (CHT) atau cukai rokok pada awal tahun 2020 ini. Rokok elektrik atau lebih dikenal sebagai vape adalah jenis penghantar nikotin elektronik. Pada awalnya rokok elektrik dirancang sebagai salah satu upaya untuk membantu perokok tembakau agar dapat berhenti merokok secara perlahan karena kandungan pada rokok elektrik terdiri dari campuran air, propilen glikol, zat penambah rasa, aroma tembakau, dan senyawa-senyawa lain yang tidak mengandung tar, tembakau atau zat-zat toksik lain yang tidak 
terdapat dalam rokok tembakau (Nancy, 2019; Widyastuti, 2020). Jadi, bagaimanapun peringatan terhadap kandungan nikotin pada rokok elektrik tetap menjadi suatu hal yang penting (Brown et al., 2020).

Pengguna rokok elektrik mengalami peningkatan sebesar $78 \%$ pengguna adalah remaja SMA dan $48 \%$ pada remaja SMP dalam satu tahun dari tahun 2017 ke 2018. Ikatan Dokter Indonesia melarang masyarakat untuk menggunakan rokok elektrik (vape) karena zatzat yang terkandung di dalamnya dapat membahayakan kesehatan. Hal ini terbukti dengan adanya kasus penyakit paru terkait vape atau yang dikenal dengan sebutan EVALI yang terjadi di Amerika Serikat. Menurut hasil yang dilaporkan terdapat lebih dari 500 pasien cedera paru-paru akibat vape (EVALI) yang terjadi di Amerika Serikat dan 8 diantaranya meninggal dunia. Amerika Serikat menetapkan penyakit ini sebagai epidemi dan hal ini berdampak sejumlah negara bagian di Amerika Serikat melarang peredaran rokok elektrik ini (Cullen et al., 2018).

Kasus cedera paru-paru terkait penggunaan rokok elektronik atau vape (EVALI) yang dilaporkan Centers for Disease Control and Prevention (CDC) pada tahun 2020 terjadi pada 48 negara bagian wilayah Amerika Serikat. Sekitar $70 \%$ pasien dari 889 pasien EVALI adalah laki-laki yang terdiri dari $80 \%$ berumr $<35$ tahun, $16 \%$ mempunyai umur $<18$ tahun, dan $21 \%$ memiliki umur 18 - 20 tahun. Pasien pengguna produk rokok elektrik yang dilaporkan meninggal dunia dari 15 negara bagian, yaitu sebanyak 18 pasien dari 578 pasien dengan rentang usia antara usia 27 hingga 71 tahun. Pasien tersebut dilaporkan telah menggunakan rokok elektrik selama tiga bulan sebelum menimbulkan gejala. Hal tersebut membuktikan bahwa rokok elektrik tidak aman seperti anggapan masyarakat mengenai rokok elektrik (Nancy, 2019).

Bahaya rokok eletrik ini sama halnya dengan rokok konvensional. Rokok elektrik ternyata juga mengandung nikotin yang merupakan zat adiktif (ketergantungan) dan dapat mempengaruhi perkembangan otak pada remaja. Pada tingkat paparan yang cukup tinggi, rokok elektrik dapat menyebabkan zat karsinogenik dan bahan toksik lainnya yang dapat menyebabkan inflamasi dan iritatif. Selain itu, rokok elektrik juga dapat menyebabkan peningkatan frekuensi batuk dan mengi pada remaja, serta peningkatan eksaserbasi asma. Asap rokok elektrik cenderung mengakibatkan permasalahan pernafasan yang lebih kompleks dibandingkan dengan asap dari rokok tembakau. Gejala tersebut akan timbul secara bertahap mulai dari sesak nafas, nyeri dada dan gangguan pernapasan lainnya (Siegel \& et al., 2019; Eaton, 2018).

Hasil penelitian yang telah dilakukan pada hewan menunjukkan bahwa rokok elektrik dapat menyebabkan inflamasi dan infeksi jaringan. Selain itu, bertambah buruknya kesehatan paru-paru, jantung, pembuluh darah, otak, hati, dan organ-organ lainnya merupakan bukti bahwa rokok elektrik mempunyai dampak yang membahayakan bagi kesehatan seperti halnya rokok tembakau. Pada pengguna rokok elektrik memiliki dampak jangka pendek yang lebih berbahaya daripada dampak jangka panjangnya. Rokok elektrik berisiko meningkatkan $56 \%$ penyakit kardiovaskular, stroke $30 \%$, dan terjadinya penyakit jantung koroner sebesar 10\% (World Health Organization, 2019).

Bukti bahwa rokok elektrik mengandung nikotin terlihat dari adanya peningkatan detak jantung pada pengguna rokok elektrik setelah menggunakan rokok elektrik ini. Bahan kimia lainnya yang terdapat dalam rokok elektrik, yaitu aerosol rokok, seperti formaldehyde dan acrolein. Kedua zat ini dapat menyebabkan kerusakan DNA pada penggunanya. Kerusakan DNA dapat menyebabkan masalah-masalah bagi kesehatan dan memiliki risiko jangka panjang, yaitu kanker (Eaton, 2018). Beberapa produk rokok elektrik yang mengandung formaldehyde dapat menyebabkan kanker. Dalam beberapa merek dagang rokok elektrik mengandung formaldehyde yang melebihi batas yang dianjurkan bagi manusia. Penelitian yang dilakukan oleh Public Library of Science Journal juga menunjukkan bahwa uap pada beberapa merek rokok elektrik mengandung kadar benzene. Menurut penelitian yang dilakukan dr. Nauki Kunugita, seorang peneliti dari National Institute of Public Health di Jepang dalam salah satu rokok elektrik ditemukan 10 kali lipat lebih tinggi tingkat karsinogen dibandingkan satu batang rokok tembakau (Bekki et al., 2014).

Dampak yang disebabkan oleh rokok elektrik juga berbahaya bagi para penderita pneumonia, gagal jantung, disorientasi, kejang, hipotensi, dan juga dapat mengakibatkan luka bakar akibat dari meledaknya rokok elektrik dalam mulut penggunanya. Kenaikan harga rokok tembakau membuat remaja di Desa Uwung Girang banyak yang beralih menggunakan rokok elektrik karena menganggap bahwa rokok elektrik lebih hemat dan kandungan nikotionnya lebih sedikit dibandingkan dengan rokok tembakau. Oleh karena itu, penulis tertarik untuk melakukan pengabdian masyarakat mengenai "Peningkatan Pengetahuan mengenai Bahaya Rokok Elektrik melalui Penyuluhan Kesehatan 
pada Remaja di Desa Uwung Girang, Tangerang" agar masyarakat dapat mengetahui dan menyadari bahwa rokok elektrik pun juga berbahaya bagi kesehatan.

\section{METODE}

Kegiatan pengabdian masyarakat ini dilaksanakan di RT. 01 RW 11 Desa Uwung Girang Kecamatan Cibodas pada bulan Agustus 2020. Mitra yang terlibat dalam program pengabdian masyarakat adalah Puskesmas dan kader di Desa Uwung Girang. Peserta dalam program pengabdian masyarakat ini adalah 30 remaja laki-laki di RT. 01 RW 11 Desa Uwung Girang Kecamatan Cibodas. Sasaran dalam program pengabdian masyarakat ini adalah peningkatan pengetahuan dan pemahaman remaja laki-laki di RT. 01 RW 11 Desa Uwung Girang Kecamatan Cibodas.

Metode yang digunakan dalam pengabdian masyarakat ini, meliputi (1) bekerja sama dengan Puskesmas setempat untuk menentukan tempat pengabdian masyarakat untuk memberikan penyuluhan kesehatan dan menentukan waktu pelaksanaan, (2) penyebaran kuesioner untuk pre test dan post test, (3) memberikan penyuluhan kepada remaja tentang bahaya rokok elektrik dengan PPT dan video, (4) pemberian alat media pembelajaran dalam bentuk leaflet, dan (5) pelaporan akhir. Sedangkan metode dalam pemberian penyuluhan kesehatan, yaitu dengan metode ceramah dengan menggunakan media audio visual, sehingga responden menjadi lebih tertarik untuk memperhatikan dan menyerap materi yang disampaikan oleh penyuluh.

\section{HASIL DAN PEMBAHASAN}

Kegiatan pengabdian masyarakat ini sebelum dan sesudah dilakukan penyuluhan kesehatan diberikan kuesioner mengenai rokok elektrik terlebih dahulu.

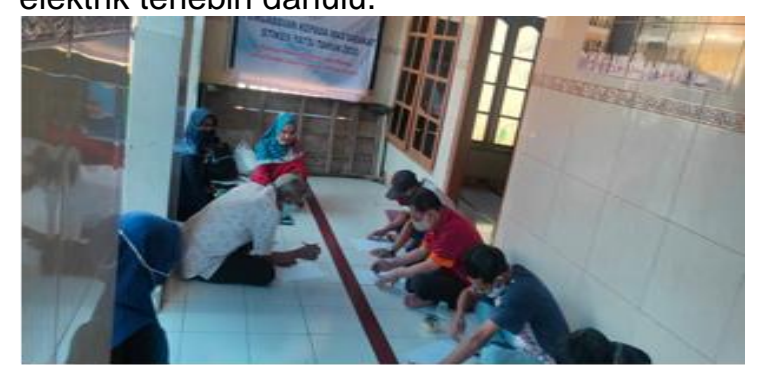

Gambar 1. Pengisian Kuesioner Rokok

Elektrik

Hasil pengabdian masyarakat ini ditunjukkan oleh penilaian kuesioner mengenai rokok elektrik. hasil tersebut ditunjukkan dalam tabel distribusi tingkat pengetahuan responden pada tabel berikut:

Tabel 1. Distribusi Pengetahuan Bahaya Rokok Elektrik $(n=30)$

\begin{tabular}{ccccc}
\hline $\begin{array}{c}\text { Tingkat } \\
\text { Pengetahuan }\end{array}$ & $\begin{array}{c}\text { Pre } \\
\text { test }\end{array}$ & Persentase & $\begin{array}{c}\text { Post } \\
\text { test }\end{array}$ & Persentase \\
\cline { 2 - 5 } & $\mathbf{n}$ & $\mathbf{\%}$ & $\mathbf{n}$ & $\boldsymbol{\%}$ \\
\hline $\begin{array}{c}\text { Baik } \\
\text { Kurang }\end{array}$ & 18 & 60 & 30 & 100 \\
$\begin{array}{c}\text { Baik } \\
\text { Total }\end{array}$ & 12 & 40 & 0 & 0 \\
\hline
\end{tabular}

(Sumber: data diolah, 2020).

$$
\text { Hasil distribusi pengetahuan }
$$

responden mengenai bahaya rokok elektrik pada 30 responden menunjukkan pada saat pre test sebanyak 18 responden $(60 \%)$ dalam kategori baik dan sebanyak 12 responden $(40 \%)$ dalam kategori kurang baik. Pengetahuan responden meningkat menjadi 30 responden $(100 \%)$ dalam kategori baik setelah diberikan penyuluhan kesehatan mengenai bahaya rokok elektrik. Hal tersebut menunjukkan bahwa terjadi peningkatan yang signifikan pada pengetahuan responden mengenai bahaya rokok elektrik.

Hasil pelaksanaan pengabdian masyarakat menunjukkan bahwa pengetahuan remaja sebelum diberikan penyuluhan kesehatan mengenai bahaya $\neg$ rokok elektrik (ecigarettes), yaitu sebanyak 18 responden $(60 \%)$ kurang baik. Sama halnya dengan penelitian menurut Damayanti (2016) menunjukkan bahwa tingkat pengetahuan sebanyak 10 responden (55.6\%) masih kurang dan sebanyak 7 responden $(50 \%)$ dalam kategori baik. Pengetahuan mengenai rokok elektrik dikatakan baik apabila dapat menjawab 6-10 pertanyaan dengan benar, sedangkan dikatakan memiliki pengetahuan kurang apabila menjawab 1-5 pertanyaan dengan benar. Sebagian besar remaja masih belum mengetahui tentang kandungan zat-zat bahan kimia yang berbahaya untuk kesehatan, baik untuk jangka pendek maupun jangka panjang.

Pada tahap akhir pengabdian masyarakat ini, penyuluh memberikan reward kepada peserta penyuluhan yang dapat menjawab pertanyaan secara lisan yang diberikan oleh penyuluh. Hal ini bertujuan untuk memberikan apresiasi dan meningkatkan motivasi kepada peserta penyuluhan agar mau dan mampu memahami materi penyuluhan kesehatan yang telah diberikan. 


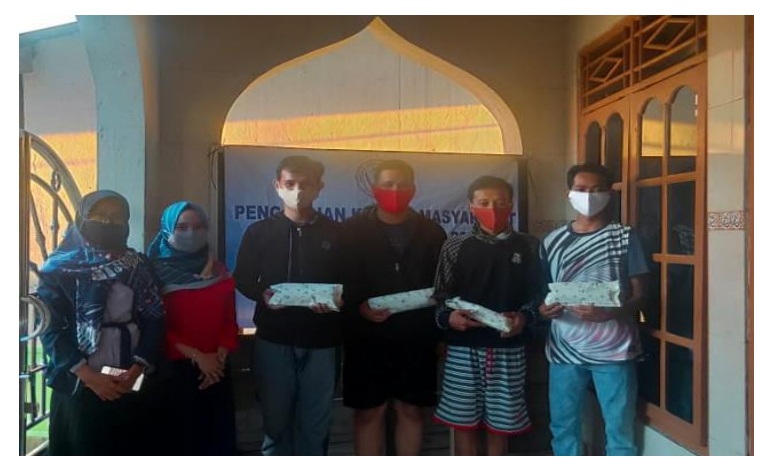

Gambar 2. Pemberian Reward kepada Peserta Penyuluhan

Sejauh ini untuk regulasi tentang rokok elektrik di Indonesia belum disosialisasikan oleh pemerintah kepada masyarakat. Hal tersebut berdampak pada masih banyaknya masyarakat, terutama remaja yang belum mengetahui tentang regulasi rokok elektrik di Indonesia. Selain itu, kebijakan pemerintah tentang rokok elektrik belum tegas diatur di Indonesia. Tidak ada koordinasi yang tepat terkait rokok elektrik antara pihak-pihak terkait (CNN, 2019).

Sedangkan setelah diberikan penyuluhan kesehatan mengenai rokok elektrik, semua responden, yaitu sebanyak 30 responden (100\%) mempunyai pengetahuan yang baik. Hal ini sejalan dengan hasil penelitian (Purnawinadi \& Kumayas, 2019) yang menunjukkan bahwa dari 63 responden, terdapat 29 responden $(46 \%)$ dalam kategori baik, 16 responden $(24.4 \%)$ dalam kategori cukup, dan 18 responden $(28.6 \%)$ dalam kategori kurang. Namun, pengetahuan yang baik belum tentu dapat merubah sikap dan perilaku merokok.

Hasil penelitian (Alawiyah, 2017) menunjukkan bahwa status penggunaan rokok elektrik yang beralih dari tembakau sebesar $76.7 \%$ dan yang langsung menggunakan rokok elektrik sebesar $23.3 \%$. Mereka mempunyai persepsi positif tentang rokok elektrik, yaitu sebesar $53.4 \%$ responden mengetahui definisi rokok elektrik dengan tepat, $50.7 \%$ responden beranggapan bahwa rokok elektrik menjadi alternatif untuk berhenti merokok tembakau, $54.8 \%$ responden mengetahui rokok elektrik berdampak buruk bagi kesehatan.

Hasil temuan dalam kegiatan pengabdian masyarakat ini responden mengatakan bahwa rokok elektrik lebih aman dibandingkan dengan rokok tembakau. Hal ini sama dengan temuan dalam penelitian (Lorensia et al., 2017). yang menunjukkan bahwa kandungan zat beracun dalam rokok elektrik lebih rendah dibandingkan dengan rokok konvensional atau tembakau. Selain itu, alasan responden mengkonsumsi rokok elektrik, yaitu untuk dapat berhenti merokok dengan mengurangi dosis nikotin yang terkandung di dalamnya secara perlahan, lebih murah apabila untuk jangka panjang dan dapat merokok dimana-mana karena tidak ada asap rokok. Penelitian (Wadsworth et al., 2016) juga menyatakan bahwa responden mengatakan bahwa rokok elektrik lebih hemat dibanding rokok konvensional.

Berbanding terbalik dengan penelitian (Yazid \& Rahmawati, 2018) mengenai rokok elektrik dan rokok konvensional merusak alveolus paru yang dilakukan pada 18 ekor tikus. Hasil menunjukkan bahwa tidak ada perbedaan yang signifikan antara kelompok paparan asap rokok konvensional dan kelompok paparan rokok elektrik. Kedua kandungan asap dari kedua rokok ini menyebabkan gambaran histologi kerusakan paru sedang dan berat. FDA (Food and Drug Administration) turut mendukung pelarangan penggunaan rokok elektrik (FDA, 2019). Bahkan beberapa negara sudah melarang sepenuhnya peredaran rokok elektrik di negaranya (BBC, 2019).

Ikatan Dokter Indonesia (IDI) menegaskan bahwa rokok elektrik dianggap sama berbahayanya dengan rokok tembakau. Beberapa penelitian menunjukkan bahwa rokok elektrik mengakibatkan terjadinya penyakit paru-paru, jantung, sistem kekebalan tubuh, kanker, dan otak (CNN, 2019). BPOM pun telah melakukan penelitian terkait rokok elektrik pada tahun 2015 dan 2017 yang menunjukkan hasil bahwa rokok elektrik menimbulkan dampak negatif untuk kesehatan. Amerika Serikat dan beberapa negara sudah membatasi peredaran rokok elektrik pada remaja. Bahkan Thailand membuat regulasi untuk membayar denda 20 juta bagi warganya yang mengkonsumsi rokok elektrik (CNN, 2018).

Ada beberapa alternatif untuk menghentikan kebiasaan merokok, yaitu dengan terapi farmakologi dan non farmakologi. Terapi farmakologi yang dapat dilakukan adalah dengan mengkonsumsi bupropion, vareniklin, klonidin. Namun, terdapat efek samping dari masing-masing obat-obatan tersebut, yaitu untuk vareniklin dapat menyebabkan gejala gastrointestinal (mual, muntah, konstipasi, dan dyspepsia), sakit kepala, insomnia, serta mimpi buruk (Fagerström \& Hughes, 2008). Untuk klonidin mempunyai efek samping mulut menjadi kering dan sedasi (Gourlay et al., 2004), sedangkan bupropion dapat menyebabkan insomnia, mulut kering, dan kejang (Wilkes, 2008).

Terapi non farmakologi salah satunya adalah mengurangi jumlah rokok yang dikonsumsi setiap harinya. Bukan mengganti 
mengkonsumsi rokok elektrik untuk menghilangkan kebiasaan atau kecanduan rokok tembakau. Karena rokok elektrik bukanlah terapi untuk menghentikan kebiasaan merokok. Hal tersebut disebabkan karena kandungan dalam rokok elektrik salah satunya adalah nikotin yang dapat menyebabkan kecanduan. Tindakan untuk berhenti merokok merupakan suatu hal yang sangat kompleks dan tidak mudah bagi para pengguna rokok, meskipun mereka mengerti akan bahaya yang diakibatkan dari merokok (Association, 2020).

Penemuan kasus baru, yaitu EVALI (ECigarette, or Vaping, product use-associated lung injury) yang disebabkan oleh penggunaan rokok elektrik dilaporkan oleh beberapa negara ke CDC. Pasien yang terkena rata-rata berusia 24 tahun dan 66\% nya adalah laki-laki. Sebanyak $82 \%$ pasien EVALI melaporkan bahwa menggunakan rokok elekrik yang mengandung tetrahydrocannabinol (THC) sebanyak 33\% dan yang rokok elektrik yang mengandung nikotin sebesar 57\%. Meningkatnya kasus EVALI ini menyebabkan CDC merekomendasikan agar masyarakat tidak mengkonsumsi rokok elektrik yang mengandung THC. Selain itu, vitamin E asetat juga tidak boleh ditambahkan ke dalam rokok elektrik. Namun hal tersebut tidak cukup mengesampingkan bahwa bahan-bahan kimia lain yang terdapat dalam rokok elektrik juga berkontribusi dalam bahan yang membahayakan bagi kesehatan (Blount et al., 2020).

\section{SIMPULAN DAN SARAN}

Penyuluhan kesehatan mengenai bahaya rokok elektrik memberikan dampak terhadap peningkatan pengetahuan dan pemahaman remaja. Hal tersebut terlihat pada peningkatan pengetahuan remaja yang kurang baik pada 18 responden (60\%) menjadi mempunyai pengetahuan yang baik $100 \%$ setelah dilakukan penyuluhan kesehatan mengenai bahaya rokok elektrik.

Rokok elektrik merupakan pengantar nikotin yang mempunyai dampak negatif terhadap kesehatan penggunanya maupun yang terpapar asap yang dihasilkan rokok elektrik. Oleh karena itu, rokok elektrik bukanlah solusi untuk mengurangi kebiasaan merokok.

Oleh karena itu, diharapkan dengan diadakannya penyuluhan kesehatan mengenai bahaya rokok elektrik terhadap masyarakat, khususnya remaja dapat lebih mengetahui dan mengubah persepsi tentang rokok elektrik, serta menyadarkan mereka untuk menghindari ataupun menghentikan konsumsi rokok elektrik maupun konvensional. Sehingga dapat terwujudkan generasi penerus bangsa yang handal, adanya peningkatan derajat kesehatan dan angka harapan hidup menjadi lebih tinggi.

\section{UCAPAN TERIMAKASIH}

Penulis pengabdian masyarakat ini mengucapkan terima kasih yang sebesarbesarnya kepada Yasasan Afiyat, Ketua STIKes Yatsi, Lembaga Pendidikan selaku Pimpinan, Penelitian dan Pengabdian kepada Masyarakat (LPPM) STIKes Yatsi Tangerang, tim panitia, dan berbagai pihak yang terlibat dalam kegiatan pengabdian masyarakat.

\section{DAFTAR RUJUKAN}

Alawiyah, S. S. (2017). Gambaran Persepsi Tentang Rokok Elektrik. Gambaran Persepsi Tentang Rokok Elektrik Pada Para Pengguna Rokok Elektrik Di Komunitas Vaporizer Kota Tangerang.

Association, A. H. (2020). 5 Steps to Quit Smoking and Vaping. Dallas, TX. https://www.heart.org/en/healthyliving/healthy-lifestyle/quit-smokingtobacco/5-steps-to-quit-smoking

Atlas, T. (2015). Consumptions. https://tobaccoatlas.org/topic/consumptio $\mathrm{n} /$

BBC. (2019). San Francisco becomes first US city to ban e-cigarettes. https://www.bbc.com/news/business48752929

Bekki, K., Uchiyama, S., Ohta, K., Inaba, Y., Nakagome, H., \& Kunugita, N. (2014). Carbonyl compounds generated from electronic cigarettes. International Journal of Environmental Research and Public Health, 11(11), 11192-11200. https://doi.org/10.3390/ijerph111111192

Blount, B. C., Karwowski, M. P., Shields, P. G., Morel-Espinosa, M., Valentin-Blasini, L., Gardner, M., Braselton, M., Brosius, C. R., Caron, K. T., Chambers, D., Corstvet, J., Cowan, E., de Jesús, V. R., Espinosa, P., Fernandez, C., Holder, C., Kuklenyik, Z., Kusovschi, J. D., Newman, C., ... Pirkle, J. L. (2020). Vitamin $E$ acetate in bronchoalveolar-lavage fluid associated with EVALI. New England Journal of Medicine, 382(8), 697-705. https://doi.org/10.1056/NEJMoa1916433

Brown, R., Bauld, L., de Lacy, E., Hallingberg, B., Maynard, O., McKell, J., Moore, L., \& Moore, G. (2020). A qualitative study of ecigarette emergence and the potential for renormalisation of smoking in UK youth. International Journal of Drug Policy, 75, 102598.

https://doi.org/10.1016/j.drugpo.2019.11. 006

CNN. (2018). Larang Peredaran Rokok Elektrik 
di Kalangan Remaja.

https://www.cnnindonesia.com/gaya-

hidup/20180913160336-255-329974/as-

larang-peredaran-rokok-elektrik-di-

kalangan-remaja/.

CNN. (2019). Tak Ada Satu Kata Kemenkes dan BPOM untuk Aturan Vape. https://www.cnnindonesia.com/gayahidup/20191005000718-255-436907/takada-satu-kata-kemenkes-dan-bpomuntuk-aturan-vape.

Cullen, K. A., Ambrose, B. K., Gentzke, A., J, A. B., Jamal, A., \& A, K. B. (2018). Use of Electronic Cigarettes and Any Tobacco Product Use Among Middle and High School Students - United States, 20112018. MMWR. Morbidity and Mortality Weekly Report, 67(45), 1276-1277. https://doi.org/10.15585/mmwr.mm6722a 3

Eaton, D. (2018). Health Effect of Electronic Nicotine Delivery Systems. National Academies Press: Washington DC.

Fagerström, K., \& Hughes, J. (2008). Varenicline in the treatment of tobacco dependence. Neuropsychiatric Disease and Treatment, 4(2), 353-363. https://doi.org/10.2147/ndt.s927

FDA. (2019). Statement from FDA Commissioner Scott Gottlieb, M.D., on advancing new policies aimed at preventing youth access to, and appeal of, flavored tobacco products, including $e$ cigarettes and cigars. https://www.fda.gov/news-events/pressannouncements/statement-fdacommissioner-scott-gottlieb-mdadvancing-new-policies-aimedpreventing-youth-access

Gourlay, S. G., Stead, L. F., \& Benowitz, N. (2004). Clonidine for smoking cessation. Cochrane Database of Systematic Reviews, 2017(12). https://doi.org/10.1002/14651858.CD000 058.pub2

Kementrian Kesehatan RI. (2018). Situasi Umum Konsumsi Tembakau di Indonesia. Situasi Umum Konsumsi Temabakau Di Indonesia, ISSN 2442-7659, 06-07.

Lorensia, A., Yudiarso, A., \& Herwansyah, F. R. (2017). Persepsi, Efektifitas Dan Keamanan Penggunaan Rokok Elektrik (E-Cigarette) Oleh Perokok Aktif Sebagai Terapi Dalam Smoking Cessation: Mixed Methods Dengan Pendekatan Studi Kuantitatif Dan Kualitatif. Journal Of Tropical Pharmacy And Chemistry, 4(2), 66-78.

https://doi.org/10.25026/itpc.v4i2.142

Nancy, Y. (2019). CDC Rilis Data Kematian
Akibat Vape dan Rokok Elektronik Baca selengkapnya di artikel "CDC Rilis Data Kematian Akibat Vape dan Rokok Elektronik", https://tirto.id/ejms. https://tirto.id/cdc-rilis-data-kematianakibat-vape-dan-rokok-elektronik-ejms

Purnawinadi, I. G., \& Kumayas, J. E. G. (2019). Pengetahuan Dan Sikap Sebagai Predisposisi Perilaku Merokok Pada Komunitas Vaper. Nutrix Journal, 3(2), 31. https://doi.org/10.37771/nj.vol3.iss2.398

Siegel, D., \& et al. (2019). Update: Interim Guidance for Health Care Providers Evaluating and Caring fo...: EBSCOhost. CDC Morbidity and Mortality Weekly Review, 68(41), 919-927. http://web.b.ebscohost.com/ehost/pdfvie wer/pdfviewer?vid=1\&sid=422b22ae476f-4684-bc3e2cc89444f943\%40sessionmgr103

Wadsworth, E., Neale, J., McNeill, A., \& Hitchman, S. C. (2016). How and why do smokers start using E-cigarettes? Qualitative study of vapers in London, UK. International Journal of Environmental Research and Public Health. https://doi.org/10.3390/ijerph13070661

Widyastuti, A. Y. (2020). Cukai Berlaku, Harga Rokok Naik Rp 5.000 Per Bungkus. https://bisnis.tempo.co/read/1291261/cuk ai-berlaku-harga-rokok-naik-rp-5-000-perbungkus

Wilkes, S. (2008). The use of bupropion SR in cigarette smoking cessation. International Journal of COPD, 3(1), 45-53. https://doi.org/10.2147/copd.s1121

World Health Organization. (2019). Report on Global Tobacco Epidemic. In World Health Organization.

https://apps.who.int/iris/bitstream/handle/ 10665/326043/9789241516204eng.pdf?ua $=1 \& u a=1$

Yazid, A. R. N., \& Rahmawati, A. A. (2018). Rokok Elektrik dan Rokok Konvensional Merusak Alveolus Paru. Prosiding Seminar Nasional Unimus, 1, 27-32. https://doi.org/2654-3168 